\title{
EFEKTIVITAS PENGGUNAAN LEMBAR KERJA BERBASIS MASALAH DENGAN BANTUAN MICROSOFT EXCEL PADA MATA KULIAH PROGRAM KOMPUTER
}

\author{
Satya Santika1, Depi Ardian Nugraha ${ }^{2}$, dan Ai Nur Solihat ${ }^{3}$ \\ Universitas Siliwangi Tasikmalaya ${ }^{1,2,3}$ \\ email: satyasantika@unsil.ac.id
}

\begin{abstract}
ABSTRAK
Pengembangan lembar kerja dapat mendukung pengembangan proses belajar mengajar. Lembar Kerja yang dibuat secara efektif dan sistematis serta fleksibel dapat membantu mahasiswa untuk belajar lebih efektif, aktif secara mandiri maupun berkelompok, sehingga diharapkan dapat meningkatkan kemandirian, keaktifan dan motivasi mahasiswa dalam proses pembelajaran pada mata kuliah program komputer. Lembar kerja yang dibuat biasanya hanya dapat diselesaikan dengan cara konvensional saja, yaitu siswa mengerjakan secara tertulis permasalahan-permasalahan yang terdapat pada lembar kerja tersebut, sehingga mahasiswa hanya terfokus pada kemampuan mahasiswa dalam memecahkan masalah saja sehingga kemampuan berpikir kreatif dan kritis mahasiswa kurang berkembang. Pada penelitian ini dikembangkan lembar kerja yang tidak hanya memfokuskan mahasiswa dalam penyelesaian masalah matematika saja, tetapi untuk merangsang kemampuan berpikir kritis dan kreatif mahasiswa dalam memecahkan masalah-masalah dalam kehidupan sehari-hari yang dapat diselesaikan dengan bantuan software microsoft excel. Sehingga penelitian ini bertujuan untuk mengetahui efektivitas penggunaan lembar kerja berbasis masalah pada perkuliahan program komputer dengan bantuan microsoft excel dan mengetahui self regulated learning mahasiswa dalam memecahkan masalah matematika pada mata kuliah program komputer dengan bantuan microsoft excel. Penelitian ini menggunakan metode research and development. Hasil penelitian menunjukkan bahwa penggunaan lembar kerja berbasis masalah dengan bantuan microsoft excel telah efektif menuntaskan $83 \%$ hasil belajar mahasiswa pada mata kuliah program komputer. Disamping itu, penggunaan lembar kerja tersebut juga meningkatkan self regulated learning mahasiswa dalam memecahkan masalah matematika. Secara umum, aspek visual activities, oral activities, dan emotional activities telah mengalami peningkatan cukup besar dibandingkan aspek listening activities dan writing activities.
\end{abstract}

Kata Kunci : Lembar kerja, Microsoft excel, Pembelajaran berbasis masalah, Self regulated learning

Dikirim: 10 Desember 2018; Direvisi: 26 Maret 2019; Diterima: 26 Maret 2019

Cara sitasi: Santika, S., Nugraha, D. A., dan Solihat, A. I. 2019. Efektivitas Penggunaan Lembar Kerja Berbasis Masalah dengan Bantuan Microsoft Excel pada Mata Kuliah Program Komputer. Jurnal Teorema: Teori dan Riset Matematika. Vol 4 No 1, Hal 23-30, Maret 2019. 


\section{PENDAHULUAN}

Peningkatan Sumber Daya Manusia (SDM) terus menerus ditingkatkan dan dikembangkan dengan beragam cara, salah satunya adalah melalui proses pendidikan. Pendidikan merupakan suatu proses yang dilalui oleh setiap individu agar memperoleh pengalaman belajar sehingga dapat mengembangkan seluruh potensi yang dimilikinya. Hal tersebut sejalan dengan Sanjaya (2010, p. 178) yang menyatakan bahwa tujuan pendidikan tidak hanya dipandang sebagai pembentukan intelektual saja, tetapi pendidikan sesungguhnya bertujuan untuk mendewasakan seseorang agar menjadi lebih baik lagi, baik dari segi intelektual, moral dan sosial. Salah satu cara untuk mencapai tujuan tersebut adalah melalui proses pembelajaran. Proses pembelajaran terus menerus dilakukan oleh seseorang pada berbagi jenjang, termasuk jenjang perguruan tinggi.

Perguruan tinggi sebagai lembaga formal bertujuan untuk mencetak manusia yang unggul, berwawasan luas, serta menguasai ilmu pengetahuan dan teknologi melalui proses pembelajaran yang berkualitas. Hal inilah yang sedang dilakukan oleh Universitas Siliwangi khususnya program studi pendidikan matematika. Pada program studi pendidikan matematika khususnya di semester genap terdapat salah satu mata kuliah yang sangat perlu dikuasai oleh mahasiswa yaitu mata kuliah program komputer. Mata kuliah ini merupakan salah satu mata kuliah yang mengasah softskill mahasiswa, di mana mahasiswa diberikan bekal keahlian yaitu merancang dan membuat sebuah program yang dapat diimplementasikan untuk perkembangan di dunia pendidikan, selain itu dalam mata kuliah ini diperkenalkan juga aplikasi-aplikasi untuk pengolah data, kalkulasi, bahkan mahasiswa harus bisa mengembangkan sendiri cara penyelesaian masalah sesuai dengan permasalahan-permasalahan yang dijumpai sehari-hari. Salah satu aplikasi yang bisa dikembangkan oleh mahasiswa adalah microsoft excel. Keunggulan dari software ini selain untuk pengolah data, microsoft excel juga dapat digunakan sebagai sarana alternatif untuk menyelesaikan permasalahan matematika yang ditemukan dalam kehidupan sehari-hari, sehingga software ini lebih bersifat fleksibel dengan beberapa fitur di dalamnya.

Kendala yang sering kali terjadi pada mata kuliah ini adalah kurangnya alokasi waktu karena bobot SKS pada mata kuliah program komputer adalah 2 SKS untuk praktikum, sehingga banyak mahasiswa yang mengeluhkan proses pembelajaran menjadi kurang efektif, selain itu banyak mahasiswa yang beranggapan bahwa mata kuliah ini hanya untuk mempelajari program komputer serta bagaimana pemanfaatannya untuk kepentingan pendidikan dan pengajaran matematika saja, padahal ruang lingkup mata kuliah ini yaitu memberikan materi tentang pengantar dasar pemrograman, pengenalan bahasa pemrograman, pernyataan, ekspresi, tipe data, variabel, operator, struktur kontrol dan fungsi. Pengembangan lebih jauh mengenai bagaimana membangun sebuah aplikasi penting yang dapat digunakan untuk menyelesaikan permasalahan-permasalahan dalam kehidupan sehari hari, tidak hanya di bidang matematika saja. Oleh karena hal tersebut, maka Dosen harus bisa mencari solusi yang efektif dan tepat.

Penelitian tentang pengembangan lembar kerja telah lama dilakukan, dari jenjang sekolah dasar hingga perguruan tinggi. Beberapa di antaranya mengangkat tema pengembangan lembar kerja berbasis pendekatan inkuiri terbimbing (Arifin, Hadisaputro, \& Susilaningsih, 2015; Asmawati, 2015; Astuti \& Setiawan, 2013; Damayanti, Ngazizah, \& Seyadi K., 2014; Estuningsih, Susantini, \& Isnawati, 2013; Purnamawati, Ertikanto, \& Suyatna, 2017), berbasis kemampuan representasi (Setiyani, 2017), berbasis masalah (Murtikusuma, 2017; Nurliawaty, Mujasam, Yusuf, \& Widyaningsih, 2017; Pariska, 2012), berbasis keterampilan proses (Anggraini, Wahyuni, \& Lesmono, 2016), berbasis Predict, Observe, Explain (Fannie \& Rohati, 2014), berbasis kecerdasan majemuk (Septiani, Ridlo, \& Setiati, 2013), strategi metakognitif (Yasir, 2013), berbasis eksplorasi, elaborasi, dan konfirmasi (Rohmad, Suhandini, \& Sriyanto, 2012), berbasis observasi (Mustofa, Ngabekti, \& Iswari, 2013), berbasis proyek (Assalma, Rahayu, \& Iswari, 2013) dan berbasis kontekstual (Aminah \& Irawati, 2018). 
Pengembangan lembar kerja berbasis masalah merupakan salah satu alternatif solusi yang diperkirakan dapat mengatasi permasalahan-permasalahan yang telah diuraikan. Lembar Kerja merupakan salah satu bahan ajar cetak yang berupa lembaran-lembaran yang berisi informasi dan petunjuk kepada peserta didik (mahasiswa) untuk mengerjakan soal-soal maupun kegiatan belajar yang berupa praktek (Dewi, Mulyati, \& Sa'dijah, 2012, para. 5), sehingga dengan adanya lembar kerja berbasis masalah maka diharapkan mahasiswa menjadi lebih efektif dalam proses pembelajaran baik dari segi waktu ataupun esensi dari mata kuliah ini.

Lembar kerja yang digunakan selama ini kurang memfasilitasi mahasiswa dalam melaksanakan pembelajaran berbasis masalah, padahal dosen memiliki banyak ide yang belum terealisasikan dalam bentuk lembar kerja. Pembelajaran berbasis masalah merupakan salah satu pendekatan dalam pembelajaran, dimana mahasiswa mengkonstruksikan pengetahuan dan pengalaman belajar yang dimilikinya dalam upaya menyelesaikan suatu masalah hingga tahap memahami masalah, menyusun dugaan dan meracang penyelesaian masalah serta membuktikan hasil yang telah diperoleh dalam menyelesaikan masalah. Melalui pembelajaran berbasis masalah diharapkan mahasiswa memiliki kemampuan menyelesaikan masalah dalam kehidupan sehari hari dengan menggunkan aplikasi software microsoft excel, baik dibidang matematika, ekonomi, biologi, geografi dan bidang lainnya.

Berdasarkan latar belakang yang telah diuraikan, maka peneliti bermaksud untuk melaksanakan peneltian untuk mengembangkan lembar kerja berbasis masalah dengan judul penelitian "Efektivitas Penggunaan Lembar Kerja Berbasis Masalah dengan Bantuan Microsoft Excel pada Mata Kuliah Program Komputer".

\section{METODE PENELITIAN}

Jenis penelitian yang akan dilakukan adalah penelitian dengan pengembangan (Research and Development $R \& D$ ), R\&D adalah metode penelitian yang digunakan untuk menghasilkan produk tertentu dan menguji keefektifan produk tersebut (Sugiyono, 2012, p. 297). Produk yang akan dikembangkan dalam penelitian ini adalah lembar kerja berbasis masalah matematika, dan untuk melihat efektivitas penggunaan lembar kerja dilakukan eksperimen.

Fokus permasalahan pada penelitian ini yaitu menyusun lembar kerja berbasis masalah, dimana soal atau perintah-perintah yang tertulis pada lembar kerja berupa permasalahan-permasalah dalam kehidupan sehari hari, baik yang berkaitan dengan bidang matematika, ekonomi atau bidang lainya yang dapat diselesaikan dengan bantuan microsoft excel, kemudian dikembangkan dalam proses pembelajaran pada mata kuliah program komputer. Setelah proses pembelajaran berlangsung maka untuk melihat efektivitas penggunaan lembar kerja berbasis masalah tersebut dilakukan eksperimen dan dilihat dari tes hasil belajar mahasiswa pada mata kuliah program komputer. Subjek penelitian ini adalah mahasiswa program studi pendidikan matematika angkatan 2016 yang terdaftar mengambil mata kuliah program komputer.

Subjek penelitian ini adalah mahasiswa program studi pendidikan matematika angkatan 2016 yang terdaftar mengambil mata kuliah program komputer dengan dosen pengampu Depi Ardian Nugraha sebanyak 2 kelas yaitu kelas $C$ dan Kelas $D$. Kelas $C$ dan D masing-masing beranggotakan 42 orang mahasiswa. Kelas $\mathrm{C}$ dijadikan sebagai kelas Eksperimen dengan proses pembelajaran yang menggunakan lembar kerja berbasis masalah dan kelas $D$ dijadikan sebagai kelas kontrol yang proses pembelajarannya tidak diberikan lembar kerja berbasis masalah dengan bantuan microsoft excel. Instrumen pada penelitian ini menggunakan tes dan angket self regulated learning (SRL) yang diadaptasi dari Latipah (2015). Tes ini digunakan untuk mengetahui hasil belajar mahasiswa setelah menggunakan lembar kerja berbasis masalah dengan bantuan microsoft excel. Melalui tes tersebut dapat ditentukan tinggi rendahnya skor dalam bentuk kuantitatif selanjutnya dibandingkan dengan standar yang telah

Dikirim: 10 Desember 2018; Direvisi: 26 Maret 2019; Diterima: 26 Maret 2019

Cara sitasi: Santika, S., Nugraha, D. A., dan Solihat, A. I. 2019. Efektivitas Penggunaan Lembar Kerja Berbasis Masalah dengan Bantuan Microsoft Excel pada Mata Kuliah Program Komputer. Jurnal Teorema: Teori dan Riset Matematika. Vol 4 No 1, Hal 23-30, Maret 2019. 
ditentukan untuk ditarik kesimpulan yang bersifat kualitatif. Angket self regulated learning (SRL) digunakan untuk mengetahui kemandirian belajar mahasiswa pada mata kuliah program komputer.

Data yang telah diperoleh melalui instrumen yang telah digunakan kemudian dianalisis secara kualitatif dan kuantitatif. Data yang diperoleh dari tes hasil belajar dianalisis dengan menggunakan perhitungan persentase mahasiswa yang memenuhi kriteria ketuntasan minimal yaitu untuk mata kuliah program komputer yaitu 80 . Pengembangan bahan ajar ini dikatakan efektif apabila lebih dari $75 \%$ mahasiswa mendapatkan skor hasil belajar 70-100. Skor yang diperoleh dari hasil menyebarkan angket, kemudian ditafsirkan dengan kriteria self regulated learning yang terdiri dari tinggi, sedang, dan rendah yang mengacu pada kriteria self regulated learning yang dikemukakan oleh Ekawati (2011, p. 37).

\section{HASIL DAN PEMBAHASAN}

Penelitian dilaksanakan mulai bulan Maret 2018, penelitian ini dilakukan pada mata kuliah Program Komputer sebanyak 4 SKS terdiri dari 2 SKS teori dan 2 SKS praktikum. Sehingga dalam pelaksanaannya penelitian ini lebih banyak dilakukan di laboratorium komputer jurusan pendidikan Matematika. Setiap mahasiswa harus mengoperasikan satu unit komputer. Penelitian ini dilakukan selama 5 pertemuan.

Pada awal kegiatan belajar atau pertemuan pertama mahasiswa terlebih dahulu diberikan angket kemandirian belajar untuk mengetahui keadaan awal sebelum diberikan lembar kerja berbasis masalah dengan bantuan MS. Excel. Setelah itu mahasiswa diberi modul penggunaan MS. Excel dan dasar-dasar pengenalan fungsi pada MS. Excel. Hal ini dilakukan agar setiap mahasiswa memiliki pemahaman yang sama dalam dasar penggunaan MS. Excel. Kemudian mahasiswa memperhatikan demonstrasi yang dilakukan oleh tim peneliti (dosen) lalu dilanjutkan dengan melakukan unjuk kerja beberapa operasi dasar pada MS. Excel. Pengenalan MS. Excel dilaksanakan sebanyak 2 pertemuan, yaitu pertemuan ke-2 dan pertemuan ke-3. Pada akhir pembelajaran siswa diberikan angket untuk mengetahui keadaan akhir setelah diberikan lembar kerja berbasis masalah dengan bantuan MS. Excel.

Pada penelitian ini setiap mahasiswa harus mengoperasikan satu komputer untuk menyelesaiakan persoalan-persoalan yang ada pada lembar kerja berbasis masalah yang dapat diselesaikan dengan bantuan MS. Excel. Kemudian tim peneliti (dosen) memberi petunjuk penggunaan MS. Excel untuk dapat digunakan sebagai media dalam membantu menyelesaiakan persoalan-persoalan matematika. Pada pertemuan ke 4, mahasiswa diberikan lembar kerja berbasis masalah, yang didalamnya berisi soal-soal pemecahan masalah matematik yang dapat diselesaikan dengan menggunakan bantuan MS. Excel. Sebelum lembar kerja tersebut diberikan kepada mahasiswa, terlebih dahulu divalidasi dan dikonsultasikan dengan 2 orang dosen di Program Studi Pendidikan Matematika yang ahli di bidang media pembelajaran matematika dan evaluasi pembelajaran matematika. Hasil dari uji ahli media pembelajaran didapatkan pencapainnya sebesar $68 \%$. Sesuai dengan penilaian lembar kuisioner maka media pembelajaran ini dikategorikan baik, sehingga layak untuk digunakan sebagai instrumen penelitian.

Pada akhir pembelajaran atau pertemuan kelima mahasiswa diberikan tes hasil belajar berupa soal-soal matematika berbasis masalah sebanyak 5 butir soal berbentuk uraian. Hal ini dilakukan untuk melihat efektivitas penggunaan lembar kerja berbasis masalah dengan bantuan MS. Excel.

Berdasarkan data hasil penelitian diperoleh sebanyak 35 orang mahasiswa dapat dikategorikan lulus atau sekitar $83 \%$, dan 7 orang mahasiswa dikategorikan belum lulus atau sekitar $17 \%$. Berdasarkan hal tersebut dapat dikatakan bahwa penggunaan lembar kerja berbasis masalah efektif meningkatkan hasil belajar mahasiswa pada mata kuliah program komputer.

Kemandirian belajar mahasiswa dapat dilihat dengan menggunakan lembar observasi selama proses pembelajaran dengan menggunaan lembar kerja berbasis masalah dengan bantuan M.S Excel dan angket kemandirian belajar yang diberikan sebelum dan setelah proses pembelajaran dengan menggunakan lembar kerja berbasis masalah dengan bantuan MS. Excel. Pada penelitian ini kemandirian

Dikirim: 10 Desember 2018; Direvisi: 26 Maret 2019; Diterima: 26 Maret 2019

Cara sitasi: Santika, S., Nugraha, D. A., dan Solihat, A. I. 2019. Efektivitas Penggunaan Lembar Kerja Berbasis Masalah dengan Bantuan Microsoft Excel pada Mata Kuliah Program Komputer. Jurnal Teorema: Teori dan Riset Matematika. Vol 4 No 1, Hal 23-30, Maret 2019. 
belajar yang diukur adalah kemandirian belajar mahasiswa yang berupa: visual activities, oral activities, listening activities, writing activities, dan emotional activities.

Tabel 1. Kemandirian Belajar Siswa Berdasarkan Lembar Observasi

\begin{tabular}{|c|l|c|c|c|c|c|c|c|}
\hline \multirow{2}{*}{ No } & \multirow{2}{*}{ Kemandirian } & \multicolumn{3}{|c|}{ Kelas Kontrol } & \multicolumn{3}{c|}{ Kelas Eksperimen } \\
\cline { 3 - 8 } & & Pretes & Postes & (g) & Pretes & Postes & (g) \\
\hline 1 & Visual Activities & $52.68 \%$ & $66.07 \%$ & 0.28 & $57.14 \%$ & $70.54 \%$ & 0.31 \\
\hline 2 & Oral Activities & $82.14 \%$ & $90.18 \%$ & 0.45 & $70.54 \%$ & $81.25 \%$ & 0.36 \\
\hline 3 & Listening Activities & $73.21 \%$ & $76.79 \%$ & 0.13 & $73.21 \%$ & $78.57 \%$ & 0.20 \\
\hline 4 & Writing Activities & $46.43 \%$ & $64.29 \%$ & 0.33 & $53.57 \%$ & $67.86 \%$ & 0.31 \\
\hline 5 & Emotional Activities & $77.68 \%$ & $87.50 \%$ & 0.44 & $78.57 \%$ & $89.29 \%$ & 0.50 \\
\hline Rata-rata & $66.43 \%$ & $76.96 \%$ & 0.33 & $66.61 \%$ & $77.50 \%$ & 0.34 \\
\hline Kriteria & Baik & Baik & Sedang & Baik & Baik & Sedang \\
\hline
\end{tabular}

Tabel 2. Kemandirian Belajar Siswa Berdasarkan Lembar Angket

\begin{tabular}{|c|l|c|c|c|c|c|c|}
\hline \multirow{2}{*}{ No } & \multirow{2}{*}{ Kemandirian } & \multicolumn{3}{|c}{ Kelas Kontrol } & \multicolumn{3}{c|}{ Kelas Eksperimen } \\
\cline { 2 - 8 } & & Pretes & Postes & $(\mathrm{g})$ & Pretes & Postes & (g) \\
\hline 1 & Visual Activities & $65.18 \%$ & $69.64 \%$ & 0.13 & $67.19 \%$ & $72.77 \%$ & 0.17 \\
\hline 2 & Oral Activities & $57.14 \%$ & $62.50 \%$ & 0.13 & $60.04 \%$ & $66.74 \%$ & 0.17 \\
\hline 3 & Listening Activities & $68.30 \%$ & $70.09 \%$ & 0.06 & $70.54 \%$ & $75.45 \%$ & 0.17 \\
\hline 4 & Writing Activities & $52.68 \%$ & $57.81 \%$ & 0.11 & $58.48 \%$ & $62.28 \%$ & 0.09 \\
\hline 5 & Emotional Activities & $55.58 \%$ & $63.84 \%$ & 0.19 & $64.73 \%$ & $70.54 \%$ & 0.16 \\
\hline Rata-rata & $59.78 \%$ & $64.78 \%$ & 0,12 & $64,20 \%$ & $69,55 \%$ & 0,15 \\
\hline Kriteria & Cukup & Cukup & Rendah & Cukup & Baik & Rendah \\
\hline
\end{tabular}

Berdasarkan Tabel 1 dan Tabel 2 dapat diketahui ada beberapa aspek yang mengalami peningkatan besar dan ada beberapa aspek yang peningkatannya kecil untuk kelas kontrol maupun kelas eksperimen. Aspek yang mengalami peningkatan cukup besar adalah aspek visual activities, oral activities, dan emotional activities. Sedangkan aspek yang peningkatannya kecil adalah aspek listening activities dan writing activities.

Visual activities, terjadi peningkatan besar karena pada awal pembelajaran mahasiswa memperhatikan langkah-langkah penggunaan media pembelajaran maupun penggunaan alat peraga. Oral activities, terjadi peningkatan besar karena pada saat pembelajaran mahasiswa sering mengajukan pertanyaan jika menemukan permasalahan dan mahasiswa sering berdiskusi untuk menyelesaikan permasalahan tersebut. Emotional activities, terjadi peningkatan besar karena mahasiswa lebih bersemangat pada saat menggunakan media pembelajaran maupun alat peraga, hal ini terjadi karena mahasiswa jarang menggunakan media pembelajaran yang menampilkan animasi dan melakukan peragaan.

Listening activities, peningkatannya kecil karena mahasiswa kurang mendengarkan penjelasan yang disampaikan oleh dosen, mahasiswa lebih berkonsentrasi pada media pembelajaran dan pedoman yang digunakan. Writing activities, peningkatannya kecil karena mahasiswa jarang membuat ikhtisar atau catatan kecil pada saat pembelajaran maupun setelah pembelajaran.

Berdasarkan Tabel 1 dan Tabel 2 dapat diketahui perbedaan kemandirian belajar mahasiswa antara lembar observasi dan lembar angket. Rata-rata peningkatan hasil kemandirian belajar kelas kontrol untuk lembar observasi sebesar 0,33 dikategorikan sedang dan lembar angket sebesar 0,12 dikategorikan rendah. Sedangkan rata-rata pencapaian hasil kemandirian belajar kelas eksperimen untuk lembar observasi sebesar 0,34 dikategorikan sedang dan lembar angket sebesar 0,15 dikategorikan rendah. Terjadi perbedaan dimana lembar observasi kelas kontrol maupun kelas eksperimen lebih tinggi dibanding lembar angket. Hal ini dikarenakan lembar observasi hanya menilai mahasiswa dari sudut pandang orang lain yaitu observer, jadi hasil yang didapatkan bisa lebih baik atau lebih jelek dari keadaan mahasiswa

Dikirim: 10 Desember 2018; Direvisi: 26 Maret 2019; Diterima: 26 Maret 2019

Cara sitasi: Santika, S., Nugraha, D. A., dan Solihat, A. I. 2019. Efektivitas Penggunaan Lembar Kerja Berbasis Masalah dengan Bantuan Microsoft Excel pada Mata Kuliah Program Komputer. Jurnal Teorema: Teori dan Riset Matematika. Vol 4 No 1, Hal 23-30, Maret 2019. 
yang sebenarnya. Sedangkan lembar angket diisi oleh mahasiswa sendiri, sehingga hasil yang didapatkan benar-benar menggambarkan keadaan mahasiswa yang sebenarnya. Tujuan digunakannya lembar observasi adalah untuk menguatkan hasil yang didapatkan lembar angket.

Hasil penelitian kelas eksperimen untuk lembar angket menunjukkan bahwa hasil kemandirian belajar mahasiswa mengalami peningkatan setelah dilakukan pembelajaran dengan model pembelajaran interaktif berbasis komputer. Walaupun peningkatan hasil kemandirian belajar mahasiswa tergolong rendah, tapi interaksi mahasiswa dengan media pembelajaran cukup bagus, ini ditunjukkan dengan antusiasme mahasiswa terhadap media yang telah disediakan. Yang menyebabkan peningkatan hasil kemandirian belajar mahasiswa rendah adalah masing-masing komputer terdapat fasilitas internet, sehingga banyak mahasiswa yang menggunakan fasilitas itu bersamaan dengan media pembelajaran yang menyebabkan terpecahnya konsentrasi mahasiswa dalam belajar. Penyebab yang lain adalah dalam pengisian angket kemandirian belajar, mahasiswa tidak sungguh-sungguh dalam pengisian angket karena tidak berpengaruh terhadap nilai akademik mereka di sekolahan. Hal inilah yang menyebabkan peningkatan hasil kemandirian belajar rendah. Akan tetapi hasil kemandirian belajar mahasiswa tetap meningkat walaupun peningkatannya rendah. Hal ini membuktikan bahwa model pembelajaran interaktif berbasis komputer mampu meningkatkan kemandirian belajar mahasiswa.

Pada pelaksanaan penelitian terdapat beberapa kekurangan antara lain ada beberapa komputer yang tidak bisa mengakses file hasil share dari komputer induk, ini yang menghambat peneliti dalam memaksimalkan waktu yang tersedia karena harus mengcopy terlebih dahulu kemudian di paste ke komputer yang bermasalah tersebut. Walaupun demikian penelitian masih bisa berjalan dengan lancar dan selesai tepat waktu karena peneliti dibantu dengan beberapa observer dalam mengcopy dan paste file media pembelajaran.

Hasil penelitian kelas kontrol untuk lembar angket menunjukkan bahwa hasil kemandirian belajar mahasiswa juga mengalami peningkatan setelah pembelajaran dengan menggunakan lembar kerja berbasis masalah. Walaupun peningkatan hasil kemandirian belajar mahasiswa tergolong rendah, tapi mahasiswa saling bekerjasama dalam melakukan percobaan, bertukar pikiran, bertukar pendapat, dan untuk menyelesaikan pertanyaan yang terdapat dalam LK. Penyebab rendahnya peningkatan hasil kemandirian belajar mahasiswa dimungkinkan karena mahasiswa tidak sungguh-sungguh dalam pengisian angket dan merasa tidak akan mempengaruhi terhadap nilai akademik secara keseluruhan. Akan tetapi hasil kemandirian belajar mahasiswa tetap meningkat walaupun peningkatannya rendah. Hal ini membuktikan bahwa penggunaan lembar kerja berbasis masalah mampu meningkatkan kemandirian belajar mahasiswa.

Pada pelaksanaan penelitian terdapat satu kekurangan sangat terlihat, yaitu pada pembelajaran dengan menggunakan lembar kerja berbasis masalah tidak setiap anggota kelompok dapat berperan aktif, sehingga cara setiap kelompok dalam merepresentasikan soal pada lembar kerja kurang maksimal. Hal ini mengakibatkan dosen harus berkeliling untuk membantu kelompok tersebut supaya pembelajaran tetap berjalan lancar.

\section{KESIMPULAN}

Penggunaan lembar kerja berbasis masalah pada perkuliahan program komputer dengan bantuan Ms. Excel efektif terhadap hasil belajar mahasiswa pada mata kuliah program komputer; hal ini terlihat kelulusan mahasiswa sebanyak $83 \%$. Penggunaan lembar kerja berbasis masalah dengan bantuan Ms. Excel dapat meningkatkatkan self regulated learning mahasiswa dalam memecahkan masalah matematika pada mata kuliah program komputer dengan bantuan Ms. Excel. Ada beberapa aspek yang mengalami peningkatan besar dan ada beberapa aspek yang peningkatannya kecil untuk kelas kontrol maupun kelas eksperimen. Aspek yang mengalami peningkatan cukup besar adalah aspek visual activities, oral activities, dan emotional activities. Sedangkan aspek yang peningkatannya kecil adalah aspek listening activities dan writing activities. 


\section{REKOMENDASI}

Penelitian ini merekomendasikan untuk penelitian selanjutnya harus memperhatikan aspek listening activities dan writing activities, karena aspek ini yang peningkatannya kecil dalam penelitian ini. Dalam pelaksanaan model pembelajaran interaktif berbasis komputer, harus diperhatikan apakah komputer benar-benar siap untuk digunakan pembelajaran. Tim peneliti (dosen) harus mempersiapkan media pembelajaran dengan baik supaya mahasiswa lebih bersemangat dalam belajar. Tim peneliti (dosen) harus mengecek apakah alat yang akan digunakan peragaan masih berfungsi dengan baik atau tidak supaya tidak mengganggu jalannya peragaan. Tim peneliti (dosen) harus mampu mengkondisikan siswa supaya jalannya pembelajaran menjadi tertib dan teratur.

\section{UCAPAN TERIMAKASIH}

Peneliti mengucapkan terima kasih kepada LP2M-PMP Universitas Siliwangi yang telah memfasilitasi dana penelitian.

\section{DAFTAR PUSTAKA}

Aminah, N., \& Irawati, I. (2018). Pengembangan perangkat pembelajaran dengan pendekatan kontekstual pada materi kubus dan balok. Jurnal Teorema: Teori dan Riset Matematika, 3 (2), 137-144. Retrieved from https://jurnal.unigal.ac.id/index.php/teorema.

Anggraini, R., Wahyuni, S., \& Lesmono, A. D. (2016). Pengembangan lembar kerja siswa (LKS) berbasis keterampilan proses di SMAN 4 Jember. Jurnal Pembelajaran Fisika, 4 (4), 350-365. Retrieved from https://jurnal.unej.ac.id/index.php/JPF.

Arifin, U. F., Hadisaputro, S., \& Susilaningsih, E. (2015). Pengembangan lembar kerja praktikum siswa terintegrasi guided inquiry untuk keterampilan proses sains. Chemistry in Education, 4(1), 54-60. Retrieved from https://journal.unnes.ac.id/sju/index.php/chemined.

Asmawati, E. Y. (2015). Lembar kerja siswa (LKS) menggunakan model guided inquiry untuk meningkatkan keterampilan berpikir kritis dan penguasaan konsep siswa. Jurnal Pendidikan Fisika, 3 (1), 1-16. https://doi.org/10.24127/jpf.v3i1.13.

Assalma, N. E., Rahayu, E. S., \& Iswari, R. S. (2013). Pengembangan lembar kerja siswa dengan pendekatan pembelajaran berbasis proyek (PBP) dan berwawasan Salingtemas. Journal of Biology Education, 2 (1), 41-49. Retrieved from https://journal.unnes.ac.id/sju/index.php/ujbe.

Astuti, Y., \& Setiawan, B. (2013). Pengembangan lembar kerja siswa (LKS) berbasis pendekatan inkuiri terbimbing dalam pembelajaran kooperatif pada materi kalor. Jurnal Pendidikan IPA Indonesia, 2 (1). https://doi.org/10.15294/jpii.v2i1.2515.

Damayanti, D. S., Ngazizah, N., \& Seyadi K., E. (2014). Pengembangan lembar kerja siswa (LKS) dengan pendekatan inkuiri terbimbing untuk mengoptimalkan kemampuan berpikir kritis peserta didik pada materi listrik dinamis sma negeri 3 purworejo kelas $\mathrm{x}$ tahun pelajaran 2012/2013. Radiasi, 3 (1).

Dewi, D. R., Mulyati, S., \& Sa'dijah, C. (2012). Pengembangan lembar kerja siswa untuk pembelajaran permutasi dan kombinasi dengan pendekatan kontekstual untuk siswa sma kelas XI. Jurnal Online Universitas Negeri Malang, 1 (1). Retrieved from http://jurnal-online.um.ac.id/

Ekawati, E., \& Sumaryanta. (2011). Pengembangan instrumen penilaian pembelajaran matematika SD/SMP. Retrieved January 1, 2016, from http://p4tkmatematika.org/file/Bermutu\%25 202011/SD/3.PENGEMBANGAN\%2520INSTRUMEN\%2520PENILAIAN\%2520PEMBELAJAR AN\%2520...pdf.

Estuningsih, S., Susantini, E., \& Isnawati. (2013). Pengembangan lembar kerja siswa (LKS) berbasis penemuan terbimbing (guided discovery) untuk meningkatkan hasil belajar peserta didik kelas xii ipa sma pada materi substansi genetika. BioEdu, 2 (1), 27-30. Retrieved from https://jurnalmahasiswa.unesa.ac.id/index.php/bioedu. 
Fannie, R. D., \& Rohati, R. (2014). Pengembangan lembar kerja siswa (LKS) berbasis POE (predict, observe, explain) pada materi program linear kelas xii sma. Sainmatika: Jurnal Sains Dan Matematika Universitas Jambi, 8 (1).

Latipah, E. (2015). Strategi self regulated learning dan prestasi belajar: Kajian meta analisis. Jurnal Psikologi, 37(1), 110-129. https://doi.org/10.22146/JPSI.7696.

Murtikusuma, R. P. (2017). Pengembangan lembar kerja siswa matematika model problem-based learning untuk smk perkebunan bertemakan kopi dan kakao. Pancaran Pendidikan, 5 (4), 5160. Retrieved from https://jurnal.unej.ac.id/index.php/pancaran.

Mustofa, M., Ngabekti, S., \& Iswari, R. S. (2013). Pengembangan lembar kerja siswa berbasis observasi pada taman sekolah sebagai sumber belajar sains. Journal of Biology Education, 2(1), 117-123. Retrieved from https://journal.unnes.ac.id/sju/index.php/ujbe .

Nurliawaty, L., Mujasam, Yusuf, I., \& Widyaningsih, S. W. (2017). Lembar kerja peserta didik (LKPD) berbasis problem solving Polya. JPI (Jurnal Pendidikan Indonesia), 6 (1), 72-81. Retrieved from https://ejournal.undiksha.ac.id/index.php/JPI.

Pariska, I. S. (2012). Pengembangan lembar kerja siswa matematika berbasis masalah. Journal Pendidikan Matematika UNP, 1(1), 75-80. Retrieved from http://ejournal.unp.ac.id/students/index.php/pmat.

Purnamawati, D., Ertikanto, C., \& Suyatna, A. (2017). Keefektifan lembar kerja siswa berbasis inkuiri untuk menumbuhkan keterampilan berpikir tingkat tinggi. Jurnal IImiah Pendidikan Fisika AlBiruni, 6(2), 209-219. https://doi.org/10.24042/jipfalbiruni.v6i2.2070.

Rohmad, A., Suhandini, P., \& Sriyanto, S. (2012). Pengembangan lembar kerja siswa (LKS) berbasis eksplorasi, elaborasi, dan konfirmasi (EEK) serta kebencanaan sebagai bahan ajar mata pelajaran geografi SMA/MA di Kabupaten Rembang. Edu Geography, 1(2), 1-5. Retrieved from https://journal.unnes.ac.id/sju/index.php/edugeo.

Sanjaya, W. (2010). Perencanaan dan desain sistem pembelajaran (1st ed.). Jakarta, Indonesia: Kencana Prenada Media Group.

Septiani, D., Ridlo, S., \& Setiati, N. (2013). Pengembangan lembar kerja siswa berbasis multiple intelligences pada materi pertumbuhan dan perkembangan. Journal of Biology Education, 2(3), 359-365. Retrieved from https://journal.unnes.ac.id/sju/index.php/ujbe.

Setiyani, S. (2017). Pengembangan lembar kerja siswa (LKS) matematika berbasis kemampuan representasi matematis pada materi statistika. Teorema: Teori Dan Riset Matematika, 2(1), 2938. Retrieved from https://jurnal.unigal.ac.id/index.php/teorema.

Sugiyono. (2012). Metode penelitian kuantitatif, kualitatif dan R\&D. Bandung, Indonesia: Alfabeta.

Yasir, M. (2013). Pengembangan lembar kerja siswa (LKS) berbasis strategi belajar metakognitif untuk meningkatkan hasil belajar siswa pada materi pewarisan sifat manusia. BioEdu, 2(1), 77-83. 